\title{
Climate Change Mitigation Technologies: Carbon Capture and Storage in the Brazilian scenario
}

\author{
Hirdan K. de M. Costa \\ Energy and Environment Institute - University of São Paulo \\ Av. Prof. Luciano Gualberto 1289 (Butanta), São Paulo, SP, Brazil \\ E-mail: hirdan@usp.br \\ Raíssa M. L. M. Musarra* \\ Energy and Environment Institute - University of São Paulo \\ Av. Prof. Luciano Gualberto 1289 (Butanta), São Paulo, SP, Brazil \\ E-mail: raissa.musarra@usp.br \\ Edmilson Moutinho dos Santos \\ Energy and Environment Institute - University of São Paulo \\ Av. Prof. Luciano Gualberto 1289 (Butanta), São Paulo, SP, Brazil \\ E-mail: edsantos@iee.usp.br \\ Colombo Celso Gaeta Tassinari \\ Energy and Environment Institute - University of São Paulo \\ Av. Prof. Luciano Gualberto 1289 (Butanta), São Paulo, SP, Brazil \\ E-mail: ccgtassi@usp.br
}

The research is financed by FAPESP - São Paulo Research Foundation (2014/50279-4) and Shell Brasil, and the strategic importance of the support given by ANP (Brazil's National Oil, Natural Gas, and Biofuels Agency) through the $R \& D$ levy regulation. This paper is an international publication originally published nationwide (Brazil) in Revista Magister de Direito Ambiental e Urbanistico $n^{\circ} 97$.

\section{Abstract}

In the present paper, it is intended to analyze how CCS (Carbon Capture, Transport, and Storage) activities are linked to the Sustainable Development Goals and how Brazil can adjust itself in regulatory terms to the activities in question, especially in the ambit of the requirements for its environmental licensing. The Environmental Impact Assessment (EIA) is a necessary support for the Environmental Licensing process of activities that cause significant environmental degradation, as it is suggested that the activities of Carbon Capture, Storage, and Transport associated with the exploration and production of oil and gas. After the assessment, the environmental agency may grant environmental licenses. Based on the analogy to existing norms in our planning, this paper presents possible alternatives to the environmental licensing of CCS activities in Brazil. Thus, from a study case, specifically, considering the potential for the construction of salt caves for carbon storage in the pre-salt area, we concluded that it is possible to draw alternatives rules to achieve offshore storage.

Keywords: Sustainable Development Goals, CCS (Carbon Capture, Transport, and Storage), Regulation, Environmental License, Salt Cavern

DOI: $10.7176 /$ RHSS/11-20-01

Publication date:October $31^{\text {st }} 2021$

\section{Introduction}

According to the IPCC Global warming of $1.5^{\circ} \mathrm{C}$ reports (2018), human activities are estimated to have caused approximately $1.0^{\circ} \mathrm{C}$ of global warming above pre-industrial levels, with a likely range of $0.8^{\circ} \mathrm{C}$ to $1.2^{\circ} \mathrm{C}$, and global warming is likely to reach $1.5^{\circ} \mathrm{C}$, between 2030 and 2052 if it continues to increase at the current rate. Also, those Climate-related risks depend on the magnitude and rate of warming, geographic location, levels of development and vulnerability, and the choices and implementation of adaptation and mitigation options (IPCC, 2018).

For the International Energy Agency (2018), carbon sequestration can be accomplished by natural means, through photosynthesis that is carbon removal from the atmosphere, or by artificial means, through Carbon Capture and Storage technologies. Captured, the carbon dioxide is compressed and transported to suitable reservoirs.

In short, the final storage of the carbon dioxide withdrawn from the atmosphere can be carried out in the hydrosphere, through ocean storage; in the biosphere, through storage by biomass; and in the lithosphere, through geological storage (Santos et al., 2017; Ferretti and Britez, 2006; Almeida et al., 2017; USEPA, 201; UK, 2018). This type of CO2 storage can be done in several geological units in the national territory and depends on 
economic, technological, and logistic vectors (Cunha et. al, 2007; Cuéllar and Azapagic, 2015; Davison, Freund and Smith, 2001; Lipponen, et. al., 2011; Singh, Stromman and Hertwich, 2011, 2012; Tapia et al., 2018).

Considering Sustainable developments goals (SDG) 7, 13, and 14 as well as the Paris Agreement (United Nations Organization, 2015), among the solutions to climate change, one may find carbon capture and storage activities as instruments to mitigate the anthropogenic emission of greenhouse gases (Cook, 2017; Corsten et al., 2018; Choptiany and Pelot, 2014). Considering its soft law nature, the Paris Agreement, as Bastian (2016) points out, each Contracting State to incorporate it into its internal regulations for applicability (also: Liu et al., 2016; Malbon, et al., 2017; Markusson, et al., 2012).

However, CCS may results in environmental damages, as CO2 leakage, thus to achieve the mitigation targets, it is important to assess this risk (Widdicombe, Blackford, and Spicer, 2013; Wood, Glasson, and Becker, 2006; Tzanidakis et al., 2013; Raza et al., 2016; Paltrinieri et al., 2013; Onyebuchi, et al., 2018; Noothout, et al.,2014; Murray et al.,2017; Mitchell, 1997; Msnuilova, Subsiri, and Wilson, 2009; Mikunda and Dixon, 2017). Besides, so far, there is no specific legislation for those activities in Brazil (Quintella et al., 2011; Rochedo et al., 2016; Rockett, 2011; Román, 2011; Román and Schott, 2011; Sathre et al., 2012; Machado, Rockett and Ketzer, 2013; Moreira et al., 2014).

Therefore, our main contribution in this research is introducing possible alternatives to rule those activities to Brazil's targets on Climate Change to be achieved. In this regard, item 2 explores the linkage between SDGs and Climate Change policies focusing on $\mathrm{CCS}$ as a tool to mitigate $\mathrm{CO} 2$ emissions.)

\section{Sustainable Developments Goals and Climate Change}

United Nations Summit on Sustainable Development promoted negotiations that were concluded in 2015 culminating in the adoption of the Sustainable Development Objectives (ODS). At the Rio +20 Conference, the ODS should guide national policies and international cooperation activities over the next fifteen years (until 2030), succeeding, and updating the Millennium Development Goals (MDGs). As early as 2013, following the guidelines issued by the Rio +20 Conference, ODSs are emerging to guide national policies and international cooperation activities, succeeding, and updating the Millennium Development Goals (MDGs) (MRE, 2018).

According to the Ministry of Foreign Affairs (MRE, 2018), Brazil participated in all sessions of intergovernmental negotiation. An agreement has been reached that includes 17 Objectives and 169 goals, involving diverse topics such as poverty eradication, food security and agriculture, health, education, gender equality, inequality reduction, energy, water and sanitation, sustainable production standards and consumption, climate change, sustainable cities, protection and sustainable use of oceans and terrestrial ecosystems, inclusive economic growth, infrastructure and industrialization, governance, and means of implementation. The Post-2015 Development Agenda and the SDGs in Brazil resulted in the document "Guiding Elements of the Brazilian Position"[1].

For Energy, the agenda intended by 2030, among other issues, promote efficient, safe and quality energy supply that contributes to economic growth, poverty reduction, and social inclusion; increase capacity building, promote innovation and the transfer of modern energy technologies; develop quality, reliable, sustainable and resilient energy infrastructure to support economic development and human well-being, with a focus on equitable and affordable access for all (MRE, 2014).

For Climate Change, the agenda includes, among other issues, promoting the cross-cutting treatment of climate change, by including it in related objectives and goals; emphasize that combating climate change is essential for the promotion of sustainable development and the eradication of poverty; emphasize the centrality of the principles and provisions of the United Nations Framework Convention on Climate Change (UNFCCC), including the principle of common but differentiated responsibilities; promote the deployment of clean energy, including low or zero-emission technologies; supporting the transfer of technology to low-carbon infrastructure and industry solutions (MRE, 2014).

All this discussion has evolved to find a neuralgic point in 2015, during the Conference of the Parties in the city of Paris, which led to the signing of the Paris Agreement (United Nations Organization, 2017), with the commitments by the signatory countries. It differs from the Kyoto Protocol, in the sense that the commitments entered into were initially drawn up by the countries themselves. In this line, a horizontal normative structuring is extracted.

Brazil presented its intended Nationally Determined Contribution (iNDC) (MMA, 2013) at the United Nations Conference on Climate Change Conference, COP 19 or CMP9, held in Warsaw in 2013, the nature of and, upon deposit of the instrument of ratification of the agreement by the Country, in September 2016, Brazil's Nationally Determined Contribution (NDC) is no longer "intended", thus, Brazil has undertaken "the commitment to implement actions and measures that support the fulfillment of the goals set at NDC. " (MMA, 2017).

In the Paris Agreement (United Nations Organization, 2015), among the solutions, carbon capture and storage activities appear as a tool to mitigate climate change (Asworth and Wade, 2015; Barros, et al., 2012; 
Beck, 2011b; Brown and Sovacool, 2011). By internalizing the Paris Agreement in 2016, adopt its principles and instruments, and it is appropriate to say that the country can legally be receiving carbon capture and storage projects (Costa et al., 2018; Bastian, 2016; Beck, 2011a; Câmara, 2011; Castelo Branco et al., 2013).

The Brazilian constitution defines as fundamental objectives of the Federative Republic of Brazil, that is to say, of the Brazilian State: to build a free, just and solidary society; ensure national development; eradicate poverty and marginalization, reduce social and regional inequalities; and promote the good of all, without prejudice of origin, race, sex, color, age, and other forms of discrimination (Article 3). Silva (2018) affirms that the 1988 Constitution, for the first time, indicates goals that are used as a basis for positive benefits that come to realize the economic, social, and cultural democracy, to effectively realize the dignity of the human person.

\section{CO2 abatement as a tool to mitigate Climate Change}

Studies show by modeling that CCS can play an important role as an emission reduction solution (Global CCS Institute, 2017; Hill et al., 2009; Iglesias et al., 2015; IPCC, 1997, 2003, 2018; IPCC/IGES, 2000; Kaarstad, Berger and Berg, 2011; Ketzer, et al., 2009; Koelbl, et al., 2016; Koorneef, Faaij and Turkenburg, 2008; Koorneef, et al., 2011).

Indicative linkages between mitigation options and sustainable development using SDGs are related to the IPCC report. The energy demand sector comprises behavioral responses, fuel switching, and efficiency options in the transport, industry, and building sector, as well as carbon capture options in the industry sector and options assessed in the energy supply sector, comprise biomass and non-biomass renewables, nuclear, carbon capture and storage (CCS) with bioenergy, and CCS with fossil fuels (IPCC, 2018).

It shows that for electricity generation, shares of nuclear and fossil fuels with carbon dioxide capture and storage (CCS) are modeled to increase in most $1.5^{\circ} \mathrm{C}$ pathways with no or limited overshoot and in modeled $1.5^{\circ} \mathrm{C}$ pathways with limited or no overshoot, the use of CCS would allow the electricity generation share of gas to be approximately $8 \%$ (3-11\% interquartile range) of global electricity in 2050 , while the use of coal shows a steep reduction in all pathways and would be reduced to close to $0 \%(0-2 \%$ interquartile range) of electricity (IPCC, 2018).

The data shows that $\mathrm{CO} 2$ emissions from industry in pathways limiting global warming to $1.5^{\circ} \mathrm{C}$ with no or limited overshoot are projected to be about $65-90 \%$ (interquartile range) lower in 2050 relative to 2010 , as compared to $50-80 \%$ for global warming of $2{ }^{\circ} \mathrm{C}$. They affirm that such reductions can be achieved through combinations of new and existing technologies and practices, including electrification, hydrogen, sustainable bio-based feedstocks, product substitution, and carbon capture, utilization, and storage (CCUS) (IPCC, 2018).

The importance given to CCS or CCUS activities in the studies is a strong indication of the need for its implementation for climate change governance. In Brazil, the incorporation of the concern with climate change finds support in the progress of incorporating environmental issues into the governmental and regulatory agendas.

Anthropogenic sources of carbon emission need to be monitored for reversal of their impacts and the capture, consisting in the process of directing the carbon dioxide to a certain structure that contains it, avoiding its dispersion in the atmosphere, through which is usually geological. This type of $\mathrm{CO} 2$ storage can be done in several geological units in the national territory and depends on economic, technological, and logistic sectors and due to the expected increase in the production of gaseous hydrocarbons in the coastal region, in the Santos, Campos, and Espírito Santo Basins (Costa et al., 2018).

These activities, therefore, can be understood as liable to cause damage to the environment, which, under the terms of item IV of article 225 of the 1988 Federal Constitution, carries out a previous environmental impact study. And, in this area, to adapt these activities to environmental regulation, it is pertinent to note that under the aegis of the instruments qualified in the National Environmental Policy Law, namely, environmental impact assessment and licensing. Considering the lack of specific legislation to deal with the themes presented here, we use the analogy in the Law of Introduction to the norms of Brazilian Law and understood as an integrative process to apply norms to cases considered as similar[2].

We can perceive that the international norms cover topics such as permits, licensing, risks, concerns with leakages and contamination of water and subsea resources and organization, and attributions of the public actors for the conduction of related administrative processes.

\section{Brazilian case: EIA System}

Environmental Impact Assessment (EIA) is a formal process structured to meet the legal requirements established by the environmental impact assessment system in which this study should be carried out and presented or study of the report examining the future environmental consequences of a proposed action (Sánchez, 2013).

Brazilian National Environmental Policy Act (NEPA) was enacted in 1981. In this regard, EIA and Environmental Licensing (EL) are key instruments to reach the objective of "preservation, improvement, and recovery of environmental quality" and "social-economic development, national security, and protection of 
human dignity". CONAMA Resolution 001/86 embraces the main EIA aspects. National Environmental Policy Act establishes that effective or potentially polluting activities must be submitted to environmental licensing (IBAMA, 2018): Article 10. The construction, installation, expansion, and operation of establishments and activities that use environmental resources, effectively or potentially polluting or capable in any way of causing environmental degradation, will depend on prior environmental licensing (NEPA, 2018).

Therefore, activities or projects that must be submitted to EIA are subject to the administrative procedure of Environmental Licensing, to avoid, minimize, repair, and compensate for possible damages caused to the environment (physical, biotic and socioeconomic means) (IBAMA, 2018).

IBAMA is the body responsible for environmental licensing in the Federal sphere. Complementary Law No. 140, dated December 8, 2011, and Decree No. 8,437, dated April 22, 2015, establish which projects should be submitted to the Federal Environmental Licensing (LAF).

According to Complementary Law No. 140, art. $7^{\circ}$, Subsection XIV, IBAMA is responsible for the environmental licensing of projects and activities that meet one of the situations offshore.

Complementary Law No. 140 was regulated by Decree No. 8,437, which establishes, without prejudice to the provisions contained in art. 7 of this Law, which undertakings or activities that will be licensed by IBAMA. According to its competency, IBAMA grants offshore previous, installation, and operation licenses.

\section{CCS activities and Environmental issues}

CCS projects are capital intensive, carry technology and integration risk, and offer limited commercial value for proponents beyond technical learning. Accordingly, the level and complexity of the policy support needed to accelerate CCS through the early deployment phase increases by an order of magnitude compared with the research and development stages. Understanding the nature and scope of existing policy support can help to highlight where greater governmental support and engagement are required. (OECD/IEA, 2016).

The Petrobras Lula Oil Field CCS Project is located approximately $300 \mathrm{~km}$ off the coast of Rio de Janeiro, Brazil. Since 2013, CO2 has been separated from the natural gas stream associated with oil production and reinjected into the producing oil reservoirs. The ultra-deep waters make the Lula field a pioneer in CO2-EOR development, with the deepest CO2 injection well in operation (Petrobras, 2015).

CO2-EOR (Enhanced Oil Recovery) Offshore Brazil - The Pre-salt Layer Background Brazil's Pre-Salt area is currently the international pioneer in pursuing deepwater offshore CO2-EOR. The Lula field is a supergiant Deepwater oil field located in the Santos Basin of Brazil. Given the innovative strategies being pursued by Petrobras, the Lula Field serves as a most valuable case study of using the early application of advanced CO2EOR technology to optimize the development of a major offshore oil field. Significant preparation steps taken at Lula, as discussed further in this section of the report, include intensive reservoir characterization, testing of alternative enhanced oil recovery options, and rigorous monitoring of pilot flood performance. Lula was discovered by Petrobras in 2006 in ultra-deep waters, between 1650 and 2,200 meters (5,400 and 7,200 feet), approximately 180 miles south-east of Rio de Janeiro. Lula's carbonate reservoir is overlain by a thick 1,800 meters $\left(6,000\right.$ feet) salt column and holds moderately light, $28-30^{\circ}$ API oil with a high solution gas-oil ratio. The associated gas in the reservoir contains $8 \%$ to $15 \%$ of CO2 (Menéndez, 2016).

Governments and industries should exploit CCS retrofitting opportunities. CCS has the unique capacity to reverse the "lock-in" of emissions from existing infrastructure. Governments should instigate a move from EOR to EOR+. With relatively small adjustments, enhanced oil recovery can generate net emissions reductions and yield verifiable storage of $\mathrm{CO} 2$.

CCS can significantly reduce the $\mathrm{CO} 2$ footprint of the primary building and other products such as steel, cement, and chemicals. Governments should take steps to create markets for clean products with low $\mathrm{CO} 2$ content. Early deployment of BECCS is needed to promote a better understanding of the potential for "negative emissions" in the future, recognizing that many climate models rely on BECCS to achieve targets of $2^{\circ} \mathrm{C}$ or below.

Differentiated business models for $\mathrm{CO} 2$ capture, transport, and storage could address some of the challenges faced by integrated projects. Industry and governments should explore novel ways of financing CCS projects, for example through a storage-centric model. CCS will be essential in delivering the ambitions of the Paris Agreement and limiting future temperature increases to well below $2{ }^{\circ} \mathrm{C}$. After 20 years of progress, the technology has been proven in many applications and should now form an important and integral part of global energy and climate strategies. The pace and intensity with which governments act to strengthen policies to meet the Paris Agreement targets will play a critical role in determining what the next 20 years of CCS will deliver (OECD/IEA, 2016).

Pre-Salt CO2-EOR highlights - Early Implementation of CO2-EOR According to Petrobras (Aspects in CO2 management in Brazilian Pre-salt Oil and Gas production - April 2014) Petrobras implemented a series of short-term EOR pilots at Lula intending to develop the entire field using CO2-EOR if the CO2 pilot was successful. According to Petrobras, early implementation of CO2-EOR would improve capital efficiency as it 
frees the operator from having to subsequently retrofit production systems and find platform space for $\mathrm{CO} 2$ recycling. Early implementation of CO2-EOR would also preclude halting operations and shutting-in oil production when undertaking CO2- EOR later in the oil field's life. - Deepwater CO2-EOR Technology The technology deployed by Petrobras for Lula mirrors the methodology and design used in ARI's deepwater CO2EOR resource assessment modeling. Similar to Petrobras, ARI uses a hub and spoke model to service multiple fields with subsea completions. Both Lula and ARI's offshore CO2-EOR design utilizes intelligent well completions, dynamic downhole monitoring, tracer injections, and extensive CO2 recycling (Menéndez, 2016).

At the First Development Phase, the first Lula EOR pilot consisted of one injection and one production well. In April 2011, Petrobras began injecting produced reservoir gas into the oil field at a rate of 35 Mcf. After six months of gas reinjection, the hydrocarbon gas was separated from the CO2 in the FPSO's membrane processing system and transported onshore for sale. The separated $\mathrm{CO} 2$ was then re-injected into the reservoir at a rate of 12.3 Mcf. A horizontal well was drilled in Q1 2012 and WAG injection, utilizing water and the high CO2 concentration gas, commenced in the second half of 2012. The Lula EOR pilot included one gas injector, two WAG injectors, and multiple producers. Ultimately, a range of pre-salt fields is using $\mathrm{CO} 2$ injection.

The major takeaway from the Lula field case study is that early implementation of CO2-EOR should be considered for giant, newly-discovered deepwater offshore fields. As demonstrated by Petrobras, phased development, reservoir simulation, and dynamic data acquisition, instead of waiting on the field's waterflood performance, can be used to define how oil recovery will respond to CO2-EOR (Menéndez, 2016).

\section{A way further: a case study on CCS and pre-salt cave}

After EIA, Brazilian laws state types of licensing. First, we have the Previous License that is issued with several conditions, the compliance with which is crucial for the granting of the Installation License, which also establishes conditions of validity, the compliance with which is fundamental for the granting of the Operation License. The issuance of both the Installation and Operation Licenses is often conditioned to specific approvals from other agencies. This overlap of authority between different agencies commonly results in conflicts of interests and delays in the implementation and operation of the activities.

The administrative competence of IBAMA in the case of the oil and gas industry for the E\&P phases for environmental licensing. Specifically, for the environmental licensing of exploration and production of oil, natural gas, and other fluid hydrocarbons (mainly unconventional activities), in 2015, Federal Decree 8.437 established the IBAMA's competence, and the MMA Ordinance 422/2011 provides for specific stages and tools for offshore activities.

In addition to the EIA, the Ordinance established some specific studies, such as the EAS Environmental Seismic Study, the Environmental Drilling Study - EAP, and the Environmental Long-Term Testing Study EATLD, which should be prepared by the entrepreneur who intends such activities, depending on the case.

Our study case is a type of $\mathrm{CO} 2$ storage that can be done in several geological units in the national territory (onshore and offshore). In this way, in fields with a high $\mathrm{CO} 2$ content in the hydrocarbon, it is possible to carry out the production, the separation of the liquid and gaseous parcels, to execute the injection of the second one (pre-salt cavern) so that, under conditions that make it physically chemically separable and with low cost, the carbon dioxide, and methane, for example. Thus, the stocking of the gaseous portion of sedimentary formations near the producer fields is among the technical solutions eligible (Costa et al., 2018).

The pre-salt area, which is full of oil and gas production and exploration, has structurally stable sites in which it is possible to construct artificial salt caves for $\mathrm{CO} 2$ storage. Salt caves can be scalable, with costs distributed throughout the development of the oil field and better utilization of energy resources. However, improperly developed activity may have a compromised structure and consequent leakage of fluids into the overlying layers or the atmosphere (Costa et al., 2018).

Under MMA Ordinance 422/11, licensing and joint studies involving more than one enterprise in the same region are possible if there is a similarity in their characteristics and time scale. As the O\&G industry's activities are carried out in large regions (blocks), it would be unjustifiable that future ventures had to repeat evaluations already carried out by other operators (Tables 1 e 2 ). 
Table 1. Licensing Framework for CCS (Offshore O\&G Industry)

\begin{tabular}{|l|l|l|}
\hline Cave located in place with EIA & $\begin{array}{l}\text { MMA Ordinance 422/11 } \\
\text { (Class 3 drilling) } \\
\text { depth of more than 1000 meters, } \\
50 \mathrm{~km} \text { or more away from the coast }\end{array}$ & $\begin{array}{l}\text { Possibility of } \\
\text { Licensing } \\
\text { Possibility of requiring further } \\
\text { studies }\end{array}$ \\
\hline Cave located in place without EIA & $\begin{array}{l}\text { MMA Ordinance 422/11 } \\
\text { (Classes 1 and 2 drilling) }\end{array}$ & $\begin{array}{l}\text { Regular Licensing } \\
\text { Need for EIA }\end{array}$ \\
\hline
\end{tabular}

Source: Elaborated by authors.

In addition, programs for control, mitigation, and compensation of environmental impacts and emergency response can be developed and implemented by multiple operators in the same region. If the drilling is classified in Class 3 of Ordinance MMA 422/11, the license to be adopted is the so-called simplified. Class 3 includes maritime drilling at a site with a depth of more than 1000 meters, more than 50 kilometers away from the coast, requiring the elaboration of an Environmental Drilling Survey (EAP).

Table 2. Scenarios for Salt Cave

1) Simplified Licensing (disposal)

- Possibility of requiring further studies

- Programs for control, mitigation, and compensation of environmental impacts and emergency response can be developed and implemented by multiple operators in the same region

2) Experimental cave (disposal)

- there are no facilitating devices in the rules, only generic principles or incentives for technological innovations

3) Disposal Central

- admitting itself as management of productive assets

- possibly require regular Licensing and EIA/RIMA due to the magnitude and specificities of the set

\section{4) Separation of Hydrocarbons}

- specificities for monitoring depending on the substances involved

- possibly require the inclusion of the ANP for the management of contracts

Source: Elaborated by authors.

Thus, IBAMA would be the competent agency and can understand that in a specific area embraces by EIA previously studies, environmental license for CCS salt carven located within an offshore oil and gas production field can be a simplified one. In this case, the process is simpler, because companies do not need to do an EIA, because they can use those previous environmental studies made for the field. If IBAMA does not understand in this way, companies shall have to do a new EIA. Therefore, there is a risk regarding the license and project timing.

There is no specific regulation for CCS in Brazil. Therefore, the environmental agencies should base their environmental evaluation for CCS activities on general rules for E\&P activities, as Petrobras (2015) has done currently in the Pre-Salt area regarding CO2EOR.

\section{Conclusion and policy implications}

Despite the lack of regulation of CCS activities in Brazil, the use of such a technique for $\mathrm{CO} 2$ emissions mitigation or reduction is aligned with the National Policy for Climate Change objectives. Thus, it is important to evaluate how the environmental licensing procedure could contribute to the development of such activity granting environmental protection (Costa et al., 2018).

It is worth remembering that Directive 2305 of 2011 of the United Kingdom establishes that a flow of $\mathrm{CO} 2$ must consist "of overwhelming" in $\mathrm{CO} 2$ (article 12). No residue or other material may be added for disposal purposes. But CO2 streams may contain incidental source associated substances, capture or injection processes, and track added substances to assist in the monitoring and verification of $\mathrm{CO} 2$ migration, as long as the concentrations of these substances are below levels that would adversely affect the integrity of the storage facility or transport infrastructure or below levels posing a significant risk to the environment or human health.

Other international standards that may be cited for CO2 as waste are Directive 2221 of 2010, the EU CO2 Storage Directive, and the EU Waste Directive, for which CO2 captured and transported for geological storage purposes does not constitute " waste "for the CO2 Storage Licensing Regulation. According to (Macrory, 2013, p. 20 ) the intention was to provide the specific regulatory framework for $\mathrm{CO} 2$ storage.

As seen, according to the applicable law, CCS activities must be subject to the environmental licensing procedure, including a complete EIA (Costa et al., 2018). The environmental impact assessment of CCS activities may be a part of a border assessment for multiple activities. Nevertheless, the specific impacts of CCS 
activities should be evaluated and approved by the competent environmental agency.

IBAMA can consider the existing EIA/RIMA, request Simplified Licensing and Complementary Studies (Ordinance 442/2011) for the construction of the cave, and observe the provisions of Law 9.966/00 for prevention, control, and inspection of pollution in offshore platforms, requiring an Emergency Plan and independent biennial audits by operators (in the case of CCS from whom to build and/or make use of the cave). IBAMA may also, regardless of the format of the licensing (simplified or regular), require the provisions of its Normative Instruction IN 01/2018, ie the Sampling Plan of Barite and Organic Base Stocks and the Fluid Monitoring Project and Gravels for approval before obtaining the environmental license.

The cited standards meet some international designations noted for environmental licensing for drilling and for seismic, as appears to require storage in a salt cave. Much progress must be made towards the monitoring of the gases in the cave after its storage, but the alternatives must arise from proper governance configurations in Brazil, in the mirror of those referred to in the international environmental norms of this study.

The ODS must be taken into account at the time of elaboration of norms, both for the laws of the territories and federal units of Brazil as for the norms of the supervisory agencies and those responsible for environmental licensing. Reliable, sustainable, modern, and affordable access to energy for all must be reconciled in the context of action to combat climate change and its impacts, without losing sight of the conservation and sustainable use of the oceans, seas, and resources for sustainable development. In all situations, CCS activities should be articulated with the availability and sustainable management of water and sanitation for all, to continue to figure as an activity minimizing the undesirable effects of pollution.

\section{References}

Abu-Khader, Mazen M (2006). Recent Progress in Co2 Capture/Sequestration: A Review. Energy Sources, Part A, 28: 1261-1279.

Almeida, José Ricardo Lemes De; Rocha, Haline De Vasconcellos; Costa, Hirdan Katarina De Medeiros; Santos, Edmilson Moutinho Dos; Rodrigues, Cristina F; Desousa, Manoel J. Lemos (2017). Analysis Of Civil Liability Regarding Ccs: The Brazilian Case. Modern Environmental Science And Engineering, V. 03, P. 382-395

Ashworth, Peta; Wade, Sarah; Reiner, David, Liang, Xi (2015). Developments In Public Communications on Ccs. International Journal of Greenhouse Gas Control 40, 449-458.

Bastian, Maria Eduarda G. A. (2016) O Acordo De Paris Como Solução Efetiva Às Questões Climáticas A Partir Uso De $\quad$ Sanções $\quad$ Premiais. $\quad$ Disponível Em Https://Www.Lume.Ufrgs.Br/Bitstream/Handle/10183/150941/001009304.Pdf?Sequence=1. Acesso Em: 12 Set. 2018.

Brasil. Constituição. Brasil (1988).

Barros, Nelson; Oliveira, Gisela; Lemos De Sousa, M. J. (2012). Environmental Impact Assessment of Carbon Capture and Sequestration: General Overview. Iaia 12 Conference Proceedings. Portugal.

Beck, Brendan; Cunha, Paulo; Ketzer, Marcelo; Machado, Haroldo; Rocha, Paulo Sergio; Zancan, Fernando; Almeida, Alberto Sampaio; Pinheiro, Diogo Zaverucha (2011a). The Current Status of Ccs Development in Brazil. Energy Procedia 4 (2011) 6148-6151.

Beck, Brenda; Garrett, Justine; Havercroft, Ian; Wagner, David; Zakkour, Paul (2011b). Development And Distribution of The Iea Ccs Model Regulatory Framework. Energy Procedia 4 (2011) 5933-5940.

Brazilian Atlas of Co2 Capture and Geological Storage (2015). Center Of Excellence in Research and Innovation in Petroleum, Mineral Resources And Carbon Storage (Cepac).

Broeckx Et Al (2016). The Plant Energy Sensor: Evolucionary Conservation and Divergence of Snrk1 Structure, Regulation, And Function, J. Exp Bot 67 (22), 6215-7252, 12.

Brown, Marylin A.; Sovacool, Benjamin K. (2011). Climate Change, And Global Energy Security. Massachusetts Institute Of Technology.

Câmara, George Augusto Batista; Andrade, José Célio Silveira; Ferreira, Luiz Eraldo Araújo; Rocha, Paulo Sérgio (2011). Regulatory Framework for Geological Storage Of Co2 In Brazil - Analyses And Proposal. International Journal of Greenhouse Gas Control 5, 966-974.

Chen, Zheng-Ao; Li, Qi; Liu, Lan-Cui; Zhang, Xia; Kuang, Liping; Jia, Li; Liu, Guizhen. (2015). A Large National Survey of Public Perceptions Of Ccs Technology In China. Applied Energy 158, 366-377.

Choptiany, John Michael Humphries; Pelot, Ronald (2014). A Multicriteria Decision Analysis Model and Risk Assessment Framework For Carbon Capture And Storage. Risk Analysis, Vol. 34; N. 9.

Cook, Peter J. (2017). Ccs Research Development and Deployment In A Clean Energy Future: Lessons From Australia Over The Past Two Decades. Engineering 3, 477-484.

Corsten, Marielle; Ramírez, Andrea; Shen, Li; Koornneef, Joris; Faaij, André (2013). Environmental Impact Assessment of Ces Chains - Lessons Learned And Limitations From Lca Literature. International Journal of Greenhouse Gas Control 13, 59-71. 
Costa, Hirdan K. De M.; Musarra, Raíssa M. L. M. (2018). Sustainable Development, And Governance: Natural Gas Consumption in The Amazon. Iosr Journal of Humanities And Social Science (Iosr-Jhss). Volume 23, Issue 9, Ver. 6, 72-81 E-Issn: 2279-0837, P-Issn: 2279-0845.

Costa, Hirdan K. De M.; Musarra, Raíssa M. L. M. (2013). Salt Cave and Experimental Activity Of Ccs (Carbon Capture And Storage) In Brazil (Mimeo).

Costa, Hirdan K. De M.; Miranda, Mariana F.; Musarra, Raíssa M. L. M. M.; Santos, Edmilson M. Dos (2018). Environmental License for Carbon Capture And Storage (Ccs) Projects In Brazil. Macrothink Institute, Journal of Public Administration And Governance Issn 2161-7104, Vol. 8, No. 3.

Costa, Hirdan K. De M.; Miranda, Mariana F.; Musarra, Raíssa M. L. M. M. (2018); The Main Environmental Licensing Requirements on Ccs Activities In Brazil. The University of Michigan. The United States.

Cuéllar-Franca, R. M; Azapagic, A. (2015). Carbon Capture, Storage and Utilization Technologies: A Critical Analysis And Comparison Of Their Life Cycle Environmental Impacts. Journal Of Co2 Utilization 9, 82102.

Cunha, Paulo; Murce, Thais; Ketzer, João Marcelo; Sartori, Cristian; Pinheiro, Diogo Zaverucha; Carvalho, Victor Cabral Da Hora Aragão De Carvalho (2007). Carbon Sequestration Technological Development in Brazil. United Nations Expert Group Meeting on Carbon Dioxide Capture And Storage And Sustainable Development. New York, September 10 to 11 th.

Davison, J.E., P. Freund, A. Smith (2001) Putting Carbon Back in The Ground, Published By Iea Greenhouse Gas R\&D Programme, Cheltenham, U.K. Isbn 1898373280.

Ferretti, A. R.; Britez, R. M. (2007). Ecological Restoration, Carbon Sequestration, And Biodiversity Conservation: The Experience of The Society For Wildlife Research And Environmental Education (Spvs) In The Atlantic Rain Forest Of Southern Brazil. Journal For Natural Conservation 14, 249-259.

Global Ccs Institute (2016). The Global Status of Ccs: 2016. Summary Report, Australia.

Global Ccs Institute (2017). The Role of Ccs In Meeting Climate Policy Targets: Understanding The Potential Contribution Of Ces To A Low Carbon World, And The Policies That May Support That Contribution.

Havercroft, Ian; Macrory, Richard (2014). Legal Liability and Carbon Capture And Storage - A Comparative Perspective. Global Carbon Capture and Storage Institute Ltd.

Hill, T A; Booth, M-J; Dorren, C; Stiff, S M; Hull (2009). Environmental Impact Study of A Power Plant With Carbon Capture And Storage Near The Uk Coast. Energy Procedia 1, 2463-2470.

Ibama (2018). Available In $<$ Www.Ibama. Gov.Br/ $>$. Accessed In: March.

Iea (2007). Technology Roadmap: Carbon Capture and Storage. Oecd/Iea, Paris.

Iea Ghg (2002). Transmission Of Co2 and Energy. Transmission Study Report, 140.

Iea Ghg (2014). Co2 Pipeline Infrastructure. 2013/18.

Iea (2018), International Energy Agency. Carbon Capture and Storage. Available At: Https://Www.Iea.Org/Topics/Carbon-Capture-And-Storage/. Accessed On: 07 Sep.

Iea (2016) 20 Years of Carbon Capture And Storage Accelerating Future Deployment.

Iglesias, Rodrigo S.; Ketzer, J. Marcelo; Melo, Clarissa L.; Haemann, Roberto; Machado, Claudia (2015). Carbon Capture and Geological Storage In Brazil: An Overview. Greenhouse Gas Sci Technol. 5: 119-130,

Ingelson, Allan; Stevenson, Flora; Costa, Hirdan K. De M. (2018) The Environmental Impact Assessment Process for Offshore Oil And Gas E\&P In Brazil (Mimeo).

Ipcc (2003): Good Practice Guidance for Land Use, Land-Use Change, And Forestry. Penman, J. Et Al. (Eds),

Ipcc/Iges, Japan. Ipcc (2000): Good Practice Guidance and Uncertainty Management In National Greenhouse Gas Inventories, J. Perman Et Al. (Eds), Ipcc/Iea/Oecd/Iges, Japan.

Ipcc, 1997: Revised 1996 Ipcc Guidelines for National Greenhouse Gas Inventories, J. T. Houghton Et Al. (Eds). Ipcc/Oecd/Iea (2003), Paris, France. Kennett, S.A.

Ipcc (2018). Global Warming Of $1.5^{\circ} \mathrm{C}$. An Ipcc Special Report on The Impacts Of Global Warming Of $1.5^{\circ} \mathrm{C}$ Above Pre-Industrial Levels And Related Global Greenhouse Gas Emission Pathways, In The Context Of Strengthening The Global Response To The Threat Of Climate Change, Sustainable Development, And Efforts To Eradicate Poverty. Summary For Policymakers.

Kaarstad, Olav; Berger, Bjorn; Berg, Svein (2011). More Than Coal - Towards A Broader Role for Ccs. Energy Procedia 4, 2662-2668.

Ketzer, J. M.; Iglesias, R.; Einloft, J.; Ligabue, R.; Lima, V. De. (2009). Water-Rock-Co2 Interactions in Saline Aquifers Aimed For Carbon Dioxide Storage: Experimental And Numerical Modeling Studies Of The Rio Bonito Formation (Permian), Southern Brazil. Applied Geochemistry 24, 760-767.

Koelbl, Barbara; Broek, Matchteld A. Van Den; Wilting, Harry C.; Sanders, Mark W. J. L.; Bulavskaya, Tatyana; Wood, Richard; Faaij, André P. C.; Vuuren, Detlef P. Van. (2016). Socio-Economic Impacts of LowCarbon Power Generation Portfolios: Strategies With And Without Ccs For The Netherlands. Applied Energy 183, 257-277.

Koorneef, Joris; Faaij, André; Turkenburg, Wim (2008). The Screening and Scoping Of Environmental Impact 
Assessment And Strategic Environmental Assessment Of Carbon Capture And Storage In The Netherlands. Environmental Impact Assessment Review 28, 392-414.

Koorneef, Joris; Ramírez, Andrea; Turkenburg, Wim; Faaij, André (2011). The Environmental Impact and Risk Assessment Of Co2 Capture, Transport, And Storage - An Evaluation Of The Knowledge Base Using The Dpsir Framework. Energy Procedia 4, 2293-2300.

Lipponen, Juho; Burnard, Keith; Beck, Brendan; Gale, John; Pegler, Bob (2011). The Iea Ccs Technology Roadmap: One Year On. Energy Procedia 4, 5752-5761.

Liu, Lan-Cui; Li, Qi; Zhang, Jiu-Tian; Cao, Dong (2016). Toward A Framework of Environmental Risk Management For Co2 Geological Storage In China: Gap And Suggestions For Future Regulations. Mitig. Adapt Strateg Glob Change, 21:191-207.

Machado, Claudia Xavier; Rockett, Gabriela Camboim; Ketzer, João Marcelo Medina (2013). Brazilian Renewable Carbon Capture and Geological Storage Map: Possibilities For The Paraná Basin. Energy Procedia 37, 6105-6111.

Macrory (2013). Sccs Co2-Eor Jip Legal Status of Co2 - Enhanced Oil Recovery; Ucl Carbon Capture Legal Programme.

Malbon, Leslie; Kita, Jun; Xue, Ziqiu (2017). Challenges For Social Impact Assessment in Coastal Regions: A Case Study Of The Tomakomai Ccs Demonstration Project. Marine Policy 83, 243-251.

Markusson, Nils; Kern, Florian; Watson, Jim; Arapostathis, Stathis; Chalmers, Hannah; Ghaleigh, Navraj; Heptonstall, Philip; Pearson, Peter; Rossati, David; Russell, Stewart (2012). A Socio-Technical Framework for Assessing The Viability Of Carbon Capture And Storage Technology. Technological Forecasting \& Social Change 79, 903-918.

Manuilova, Anastassia; Suebsiri, Jitsopa; Wilson, Malcolm (2009). Should Life Cycle Assessment Be Part of The Environmental Impact Assessment? Case Study: Eia of Co2 Capture And Storage In Canada. Energy Procedia 1, 4511-4518.

Menéndez, Marcos Barrero (2016). Offshore Co2 Enhanced Oil Recovery with Ccs Programs, Club Español De La Energía, Enerclub, File:///H:/Padr\%C3\%A3o/Downloads/02_2_Finalista_Offshore_Co2_Enhanced_Oil_Recovery_With_Ccsp rograms_Marcos_Barrero.Pdfmello, Celso De. Adi 3.540 Mc, Rel. Min. Celso De Mello, J. Stf. $1^{\circ}{ }^{\circ}-9-2005$, $\mathrm{P}, \mathrm{Dj}$.

Mikunda, Tom; Dixon, Tim (2017). Review Of Project Permits Under the London Protocol - An Assessment Of The Proposed P18-4 Co2 Storage Site. Energy Procedia 114, 7431-7442.

Ministério Das Relações Exteriores (2018), Http://Www.Itamaraty.Gov.Br/Pt-Br/PoliticaExterna/Desenvolvimento-Sustentavel-E-Meio-Ambiente/134-Objetivos-De-Desenvolvimento-SustentavelOds, Access In 2018.

Ministério Das Relações Exteriores, Negociações Da Agenda De Desenvolvimento Pós-2015: Elementos Orientadores Da Posição Brasileira, 2014.

Ministério Do Meio Ambiente (2017). Contribuição Nacionalmente Determinada. Ndc Do Brasil. Disponivel Em Http://Mma.Gov.Br/Clima/Ndc-Do-Brasil

Ministério Do Meio Ambiente (2018). Pretendida Contribuição Nacionalmente Determinada (Indc, Na Sigla Em

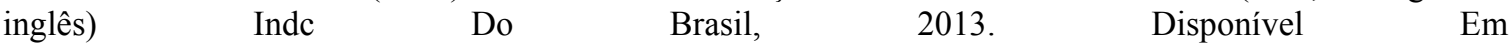
Http://Redd.Mma.Gov.Br/Pt/Images/Publicacoes/Brasil\%20indc\%20portugus\%20final.Pdf

Mitchell, J (1997), "Mitigation in Environmental Assessment — Furthering Best Practice", Environmental Assessment, 5(4), Pages 28-29.

Moreira, Andréa Cristina De Castro Araujo; Musse, Ana Paula Santana; Rosário, Fátima Do; Lazzarin. Helen Simone Chiaranda; Cavelhão; Chang, Hung Kiang; Oliva, Andresa; Landulfo, Eduardo; Nakaema, Walter Morinobu; Melo, Clarissa Lovato (2014). The First Brazilian Field Lab Fully Dedicated to Co2 Mmv Experiments: From The Start-Up To The Initial Results. Energy Procedia 63, 6227-6238.

Murray, Fiona; Widdicombe, Stephen; Mcneill, C. Louise; Douglas, Alex (2017). Assessing The Consequences of Environmental Impacts: Variation In Species Responses Has Unpredictable Functional Effects. Marine Ecology Progress Serie, Vol. 583:35-47.

Noothout, Paul; Wiersma, Frank; Hurtado, Omar; Macdonald, Doug; Kemper, Jasmin; Alphen, Klass Van. (2014). Co2 Pipeline Infrastructure - Lessons Learned. Energy Procedia 63, 2481-2492.

Oliveira, I. S. D. De; Montaño, M.; Souza, M. P. De (2009). Avaliação Ambiental Estratégica. São Paulo: São Carlos: Suprema.

Onyebuchi, V.E.; Kolios, A.; Hanak, D. P.; Biliyok, C.; Manovic, V. (2018). A Systematic Review of Key Challenges Of Co2 Transport Via Pipelines. Renewable And Sustainable Energy Reviews 81, 2563-2583.

Paltrinieri, Nicola; Breedveld, Leo; Wilday, Jill; Cozzani (2013). Identification Of Hazards and Environmental Impact Assessment For An Integrated Approach To Emerging Risks Of Co2 Capture Installations. Energy Procedia 37, 2811-2818. 
Petrobras Santos Basin Pre-Salt Oil Field Ccs (2018). Available In: $<$ Https:/Www.Globalccsinstitute.Com/Projects/Petrobras-Santos-Basin-Pre-Salt-Oil-Field-Ccs-Project $>$.

Quintella, Cristina M.; Meira, Marilena; Miyazaki, Sabrina Freire; Costa Neto, Pedro Ramos Da; Souza, Gerardo Gerson Bezerra De; Hatimondi, Sueli Akemi; Musse, Ana Paula Santana; Moreira, Andrea De Araujo; Dino, Rodolfo (2011). Brazilian Potential for Ccs For Negative Balance Emission Of Co2 From Biomass Energy. Energy Procedia 4, 2926-2932.

Raza, Arshad; Rezaee, Reza; Gholami, Raoof; Bing, Chua Han; Nagarajan; Hamid, Mohamed Ali Hamid (2016). A Screening Criterion for The Selection Of Suitable Co2 Storage Sites. Journal Of Nature Gas Science and Engineering 28, 317-327.

Rochedo, Pedro R. R.; Costa, Isabella V.L.; Impèrio, Mariana; Hoffmann, Bettina Susanne; Merschmann, Paulo Roberto De C.; Oliveira, Camila C. N.; Szklo, Alexandre; Schaeffer, Roberto (2016). Carbon Capture Potential and Costs In Brazil. Journal Of Cleaner Production 131, 280-295.

Rockett, Gabriel Camboim; Machado, Claudia Xavier; Ketzer, João Marcelo Medina; Centeno, Caroline Inda (2016). The Carbmap Project: Matching Co2 Sources and Geological Sinks In Brazil Using Geographic Information System. Energy Procedia 4, 2764-2771.

Román, Mikael (2011). Carbon Capture and Storage In Developing Countries: A Comparison Of Brazil, South Africa, And India. Global Environmental Change, 21, 391-401.

Román, Mikael; Schott, Fábio Saraiva (2011). Sleipner And Pre-Salt: The Competitive Strategic Concerns of Promoting Ccs In Norway And Brazil. Sciencedirect. Energy Procedia 4, 5721-5728.

Sathre, Roger; Chester, Mikhail; Cain, Jennifer; Masanet, Eric (2012). A Framework for Environmental Assessment Of Co2 Capture And Storage Systems. Energy 37 540-548.

Sato, Toru; Kamada, Kentaro; Fukumoto, Ayako; Nakashima, Takuya; Tao, Yu; Oyama, Hiroyuki (2016). Environmental Impact Assessment Technologies for Sub-Sea Geological Ccs. Techno-Ocean, P 454-459.

Sanches, Luis Enrique (2013). Avaliação De Impacto Ambiental - Conceitos E Métodos. São Paulo: Ofícina De Textos, 2 Ed.

Santos, E. M.; Costa, Hirdan Katarina De Medeiros ; Romeiro, V. ; Parente, V. (2016). Energia De Combustíveis Fósseis E A Captura E Armazenamento De Co2. In: Lineu. (Org.). Sustentabilidade E Energia. São Paulo: Manole, P. 209-247.

Silva, José Afonso Da (2018). Curso De Direito Constitucional Positivo. 41ª Ed. São Paulo: Malheiros.

Singh, Bhawna, Stromman, Anders H.; Hertwich, Edgar G. (2011). Comparative Impact Assessment of Ccs Portfolio: Life Cycle Perspective. Energy Procedia 4, 2486-2493.

Singh, Bhawna, Stroman, Anders H.; Hertwich, Edgar G. (2012). Environmental Damage Assessment of Carbon Capture And Storage. Journal Of Industrial Ecology, Vol. 16, N. 3.

Tapia, John Frederick D.; Lee. Jui-Yuan; Ooi, Raymond E. H.; Foo, Dominic C. Y.; Tan, Raymond R. (2018). A Review of Optimization And Decision-Making Models For The Planning Of Co2 Capture, Utilization, And Storage (Ccus) Systems. Sustainable Production and Consumption 13, 1-15.

Tzanidakis, Konstantinos; Oxley, Tim; Cockerill, Tim; Apsimon, Helen (2013). Illustrative National Scale Scenarios of Environmental And Human Health Impacts Of Carbon Capture And Storage. Environment International 56, 48-64.

Usepa (2010). General Technical Support Document for Injection And Geologic Sequestration Of Carbon Dioxide: Subparts $\mathrm{Rr}$ And Uu. Greenhouse Gas Reporting Program. (2010). Http://Www.Epa.Gov/Ghgreporting/Documents/Pdf/2010/Subpart-Rr-Uu_Tsd.Pdf.

Uk - Environmental Agency. Available In: Https:/Www.Gov.Uk/Government/Uploads/System/Uploads/Attachment_Data/File/297115/Geho0811buc q-E-E.Pdf. Accessed In March 2018.

Widdicombe, S., Blackford, J. C.; Spicer, J. I (2013). Assessing The Environmental Consequences of Co2 Leakage From Geological Ccs: Generating Evidence To Support Environmental Risk Assessment. Mar. Pollut. Bull. 73, 399-401.

Wood, Graham; Glasson, John; Becker, Julia (2006). Eia Scoping in England And Wales: Practitioner Approaches, Perspectives, And Constraints. Environmental Impact Assessment Review 26, 221-241.

\section{Notes}

Note 1. The Post 2015 Agenda corresponds to the whole set of programs, actions, and guidelines that will guide the work of the United Nations and its member countries towards sustainable development after 2015. Building on international experience with the Development Goals of the Millennium Development Goals (MDGs), which expire in 2015, the challenge of the new Development Agenda is to structure, simultaneously and in a balanced way, global efforts to eradicate poverty and effectively integrate the economic, social and environmental dimensions of development sustainable development. Unlike the MDGs, which proposed sectoral goals, the post-2015 agenda should have a comprehensive and universal perspective, with commitments that apply to both 
developing and developed countries. (MRE, 2018). The Supreme Federal Court had the opportunity to manifest itself in constitutionality control over the goal of national development and the preservation of the integrity of the environment ( $\mathrm{CF}$, art. 225), at which time Minister Celso de Mello analyzed the issue of national development (CF, article 3, II) and the need to preserve the integrity of the environment (CF, article 225) raising the environmental issue to an unavoidable condition, one of the most fundamental rights.

Note 2. When the law is silent, the judge will decide the case according to the analogy, customs, and general principles of law. Available at: http://www.planalto.gov.br/ccivil_03/Decreto-Lei/Del4657compilado.htm. Access in: ago. 2018. 